\title{
WeMO effects on the amount and the chemistry of winter precipitation in the north-eastern Iberian Peninsula
}

\author{
R. Izquierdo ${ }^{1}$, M. Alarcón ${ }^{2}$ and A. Àvila ${ }^{1}$ \\ ${ }^{1}$ CREAF, Universitat Autònoma de Barcelona, Bellaterra, 08193, Barcelona \\ ${ }^{2}$ Departament de Física i Enginyeria Nuclear, Universitat Politècnica de Catalunya, c/ Urgell 187, 08036, Barcelona \\ Received: 1-VII-2013 - Accepted: 16-XII-2013 - Original version
}

Correspondence to: anna.avila@uab.cat

\begin{abstract}
The cluster classification of provenances at a site in the NE Iberian Peninsula indicated that in the period of extended winter (December to March, DJFM) fast Atlantic air flows correspond to positive WeMO index (WeMOi), while negative WeMOi are associated to Mediterranean circulations. The amount of winter precipitation was inversely correlated with winter WeMOi. Wet deposition fluxes of marine-derived $\left(\mathrm{Na}^{+}, \mathrm{Mg}^{2+}\right.$ and $\left.\mathrm{Cl}^{-}\right)$and anthropogenic-derived $\left(\mathrm{NO}_{3}^{-}\right.$ and $\mathrm{K}^{+}$) ions were significantly (and negatively) related to winter WeMOi. The negative phase of WeMO causes the entry of air masses from the Mediterranean into the Iberian Peninsula, that are enriched with marine ions. For $\mathrm{NO}_{3}^{-}$this result suggests the advection over the Mediterranean of polluted air masses from southern Europe and the scavenging and deposition of this pollution by rain during WeMO negative phases. This will carry long-range pollutants to the NE Iberian Peninsula, but local pollutants may also contribute, as precipitation events from the Mediterranean (associated to negative WeMOi) may incorporate local anthropogenic emissions that build up during the winter anticyclonic episodes typical of the region.
\end{abstract}

Key words: precipitation, West Mediterranean, rain chemistry, deposition, cluster analysis, back-trajectories, WeMO

\section{Introduction}

The atmospheric dynamics in the west Mediterranean basin are conditioned by complex interactions of climatic and topographic effects that include: 1) the Azores highpressure system, 2) continental thermal lows over the Iberian Peninsula (hereafter IP) and the Sahara, 3) orographic effects of the coastal ranges surrounding the Mediterranean coast, 4) marked seasonal variations in temperature, humidity and rainfall, and 5) the arrival of frequent African dust intrusions (Millán et al., 1997; Rodríguez et al., 2003). The $4^{\text {th }}$ Intergovernmental Panel on Climate Change indicated a precipitation increase in high latitudes and a decrease in the Mediterranean area in a future warmer climate (IPCC, 2007). However, the projected changes in rainfall show a marked latitudinal gradient in the area. Thus, in the southern Mediterranean (including Southern IP) the decline could exceed 20\%, while in Catalonia (NE IP) decreases in rainfall of $10-15 \%$ on an annual scale are expected (Calbó et al., 2012). Gonzalez-
Hidalgo et al. (2009) indicate that the IP, and particularly its Mediterranean fringe, is an area of confluence of several atmospheric patterns acting synchronically with different intensity and effects on precipitation.

The Western Mediterranean Oscillation (WeMO) climatic variability has been defined within the synoptic framework of the western Mediterranean basin (Martín-Vide and López-Bustins, 2006). The WeMO index consists of the difference between the standardized surface pressure values recorded at Padua $\left(45.40^{\circ} \mathrm{N}, 11.48^{\circ} \mathrm{E}\right)$ in northern Italy, an area with a relatively high barometric variability due to the influence of the central European anticyclone, and San Fernando (Cadiz) $\left(36.28^{\circ} \mathrm{N}, 6.12^{\circ} \mathrm{W}\right)$ in south-western Spain, an area often influenced by the Azores anticyclone (Figure 1). This regional barometric pattern has been found to greatly determine the rainfall variability on the eastern side of the Iberian Peninsula (Martín-Vide and López-Bustins, 2006; Gonzalez-Hidalgo et al., 2009). As in most of the variability patterns of the Northern Hemisphere, WeMO shows its most 


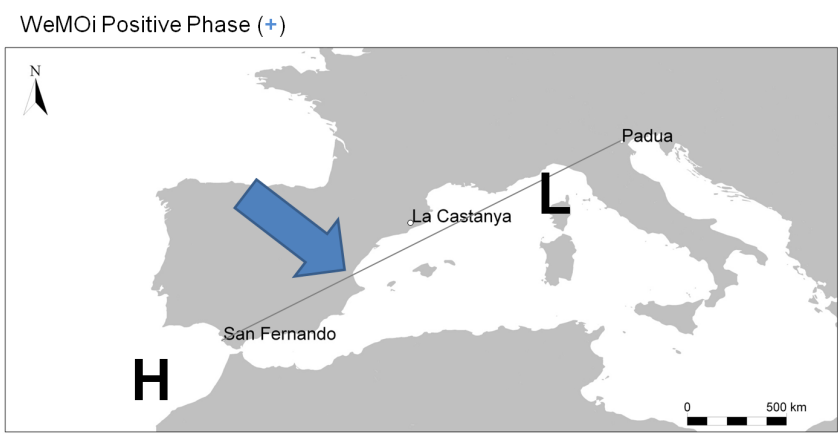

Figure 1. WeMO phases.

relevant dynamics during the cold half of the year (MartínVide and López-Bustins, 2006).

The atmospheric pollution climate in the NE IP is modulated by mesoscale and local/regional processes, which have been extensively described by Millán et al. (1991, 1997), Pérez et al. (2008), Pey et al. (2009, 2010), Querol et al. (2004) and Salvador et al. (2007) among others. The region is subject to a large load of anthropogenic emissions from the intense activity of large cities such as Marseille, Barcelona and Tarragona, their industrial surroundings, as well as highways of intense traffic. Also natural emissions (from soil dust and marine aerosols) contribute to the aerosol load in the region (Escudero et al., 2006, 2007; Pey et al., 2009; Salvador et al., 2007). This produces a complex set of interactions with a high degree of secondary aerosol formation and an intensive interaction of gaseous and aerosol components (Pérez et al., 2008; Pey et al., 2009). The build up of pollutants is further affected by a marked seasonality. In winter, the frequent entry of relatively clean Atlantic air fluxes induces the replacement of air masses, thus reducing the levels of atmospheric pollutants that may have accumulated during periods of anticyclonic stability (Rodríguez et al., 2003; Escudero et al., 2007). In contrast, the synoptic scenario in summer is characterized by very weak pressure gradients in the western Mediterranean which produce local circulations enhancing the regional accumulation of pollutants (Millán et al., 1991, 1997; Rodríguez et al., 2003). The frequency of precipitation also has an impact on the levels of atmospheric pollutants.

Aerosols and gases are incorporated in rainwater through the process of rainout (incorporation as cloud condensation nuclei or droplets) or washout (scavenged as rain falls). Therefore the chemical composition of the precipitation is strongly influenced by the predominant atmospheric transport patterns, due to the scavenging of pollutants as clouds cross polluted areas, and to rainfall amounts, in which case there is a dilution, thus decreasing the concentration of components in rain. Rain concentrations reflect both processes and thus provide a chemical signature of the interaction between water droplets and the ambient gases and aerosols (Seinfeld and Pandis, 1998). Deposition is defined
WeMOi Negative Phase (-)
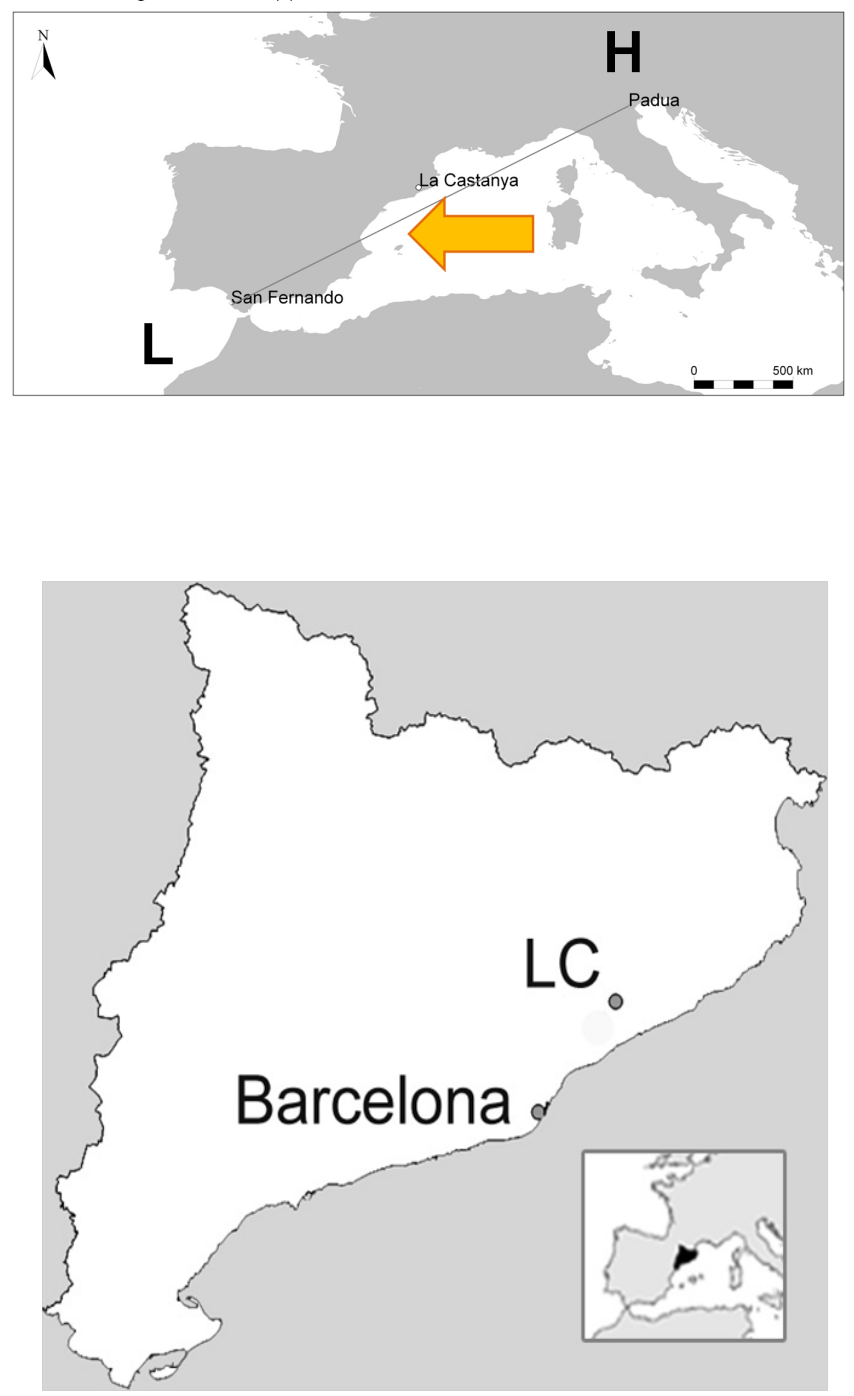

Figure 2. Location of La Castanya study site (LC).

as the process by means of which gases and aerosols are transferred to the ground. The vehicle of transfer can be water (such as rain, mist or snow), in which case the term wet deposition is used (Seinfeld and Pandis, 1998), but gases and particles can also be deposited in the dry mode, in which case the transfer to the ground is mostly effected through turbulent transfer and gravitational settling (Lovett, 1994). While dry deposition has been found to play a role in the total deposition amounts in the NE IP (Izquierdo and Àvila, 2012), here we will deal only with wet deposition.

The WeMO positive phase has been shown to trigger air fluxes from the Atlantic, while its negative phase is associated to flows from the Mediterranean (Martín-Vide and López-Bustins, 2006; López-Bustins et al., 2008); therefore, it can be foreseen that part of the chemical variability of precipitation in the NE IP may be related to the WeMO pattern. Despite the well-known relationship between the WeMO pat- 

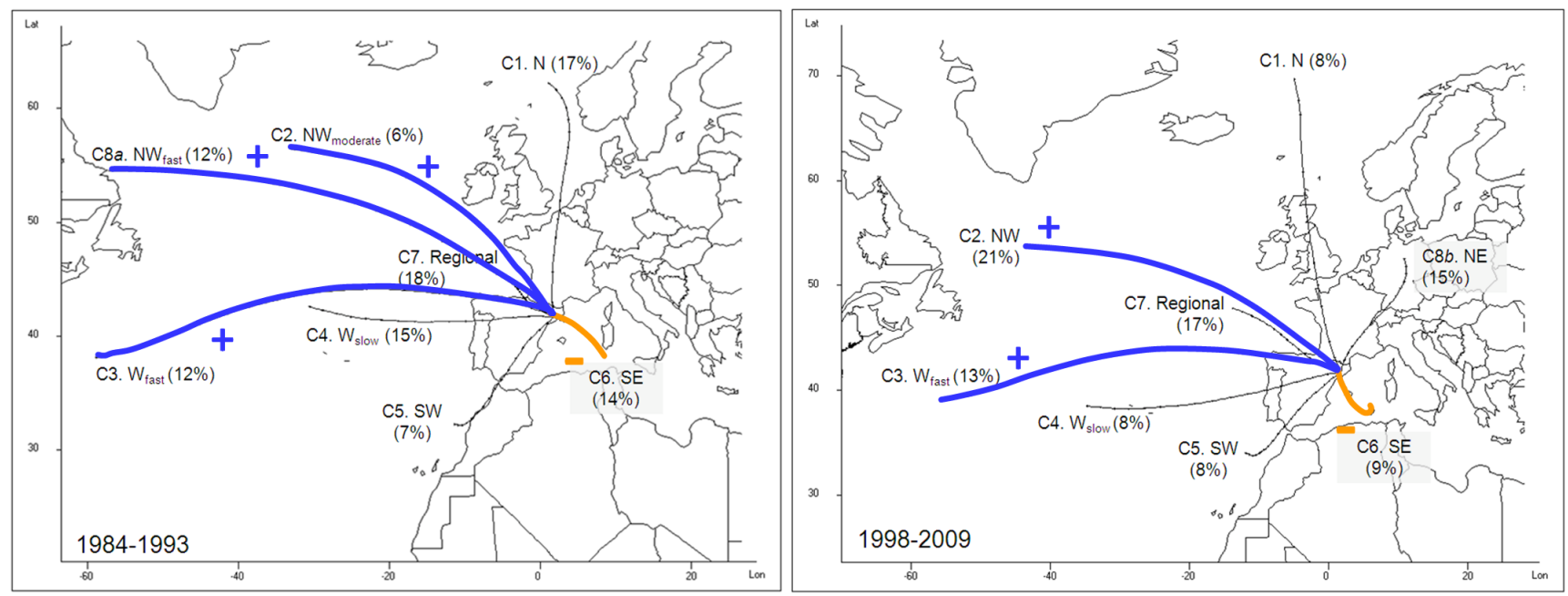

Figure 3. Back-trajectory centroids and frequency associated to each winter (DJFM) cluster. Back-trajectories (72 h) from LC calculated at 1500 m a.s.l. Two periods are compared: an initial period from 1984 to 1993 and a recent period from 1998 to 2009.

tern and rainfall amounts in NE Spain (López-Bustins et al., 2008; Gonzalez-Hidalgo et al., 2009), very few studies have been devoted to analyzing their influence on the rain chemical composition. To categorize the incoming fluxes we have used cluster analysis.

We hypothesize here that part of the chemical signature of the rain and/or the wet deposition amounts reaching a site in Catalonia may be influenced by the Mediterranean climatic variability defined by the WeMO index (WeMOi). To check this hypothesis, we analyze the relationship between the WeMOi and the chemical composition of the groupings obtained in the clustering exercise. This is explored for the extended winter (DJFM) period, when WeMOi has a stronger effect on precipitation (Martín-Vide and LópezBustins, 2006) using precipitation chemistry data from a locality in Catalonia.

\section{Material and methods}

La Castanya station (LC, $41^{\circ} 46 \mathrm{~N}, 2^{\circ} 21 \mathrm{E}, 700 \mathrm{~m}$ a.s.1.) is located in the Montseny mountains, which are part of the Pre-litoral Catalan Range. The site is in the middle of extensive holm-oak (Quercus ilex L.) forests in the Montseny Natural Park, $40 \mathrm{~km}$ to the N-NE of Barcelona and $25 \mathrm{~km}$ from the Mediterranean coast (Figure 2).

Weekly precipitation samples were collected for chemical analysis with 2 bulk deposition collectors (consisting of a polyethylene funnel connected to a 10-1 bottle) located in a clearing within the holm oak forest. Further details can be found in Izquierdo and Àvila (2012) and Izquierdo et al. (2012). Samples were processed in the CREAF laboratory according to previously described protocols (Àvila, 1996; Àvila and Rodà, 2012). Conductivity, alkalinity and $\mathrm{pH}$ were measured in unfiltered samples within $48 \mathrm{hr}$ of sampling. Samples were filtered through $0.45 \mu \mathrm{m}$ membrane filters and stored at $-20^{\circ} \mathrm{C}$. Ion chromatography was used to determine the concentrations of $\mathrm{Na}^{+}, \mathrm{K}^{+}, \mathrm{Mg}^{2+}, \mathrm{Ca}^{2+}$, $\mathrm{NH}_{4}^{+}, \mathrm{Cl}^{-}, \mathrm{NO}_{3}^{-}$and $\mathrm{SO}_{4}^{2-}$. Analytical quality was checked with the ratios of measured conductivity to calculate conductivity and the ratio of sum of cations/sum of anions, with a $20 \%$ allowance around the expected value (1). Analytical accuracy was checked with the repeated inclusion of certified samples in analytical runs. Rain chemical concentrations were weighted by the precipitation amount to obtain volume weighted means (VWM). Bulk deposition amounts were calculated as the product of VWM rain concentrations times the amount of precipitation. To associate a weekly rain concentration to daily back trajectories, a daily chemical concentration for the days with precipitation was estimated by proportionally correcting weekly chemical concentrations by the precipitation contribution of the rainy days to the weekly amount. Further details can be found in Izquierdo et al. (2012). 2001, 2004 (for base cations) and 2005 were not included due to fragmentary sampling.

Daily 96-h isosigma back-trajectories at 12:00 UTC and $1500 \mathrm{~m}$ a.s.l. were calculated using the HYSPLIT (Hybrid Single-Particle Lagrangian Integrated Trajectory) 4.0 dispersion model from the Air Resources Laboratory (ARL, available at http://www.arl.noaa.gov/ready/hysplit4.html, Draxler and Rolph, 2003; Draxler et al., 2009) (see Izquierdo et al., 2012 for more details). The meteorological input was obtained from the ARL reanalysis database for the early 10year monitoring period (1984-1993), and from FNL (19982004) and GDAS (Global Data Assimilation System) (20052009) from the NCEP (National Center for Environmental Prediction) for the most recent period (1998-2009). Even though the WeMO index corresponds to surface level pressures, a height of $1500 \mathrm{~m}$, corresponding to $850 \mathrm{hPa}$ standard pressure level, was selected for trajectory computation because both levels can be considered comparable for synoptic 

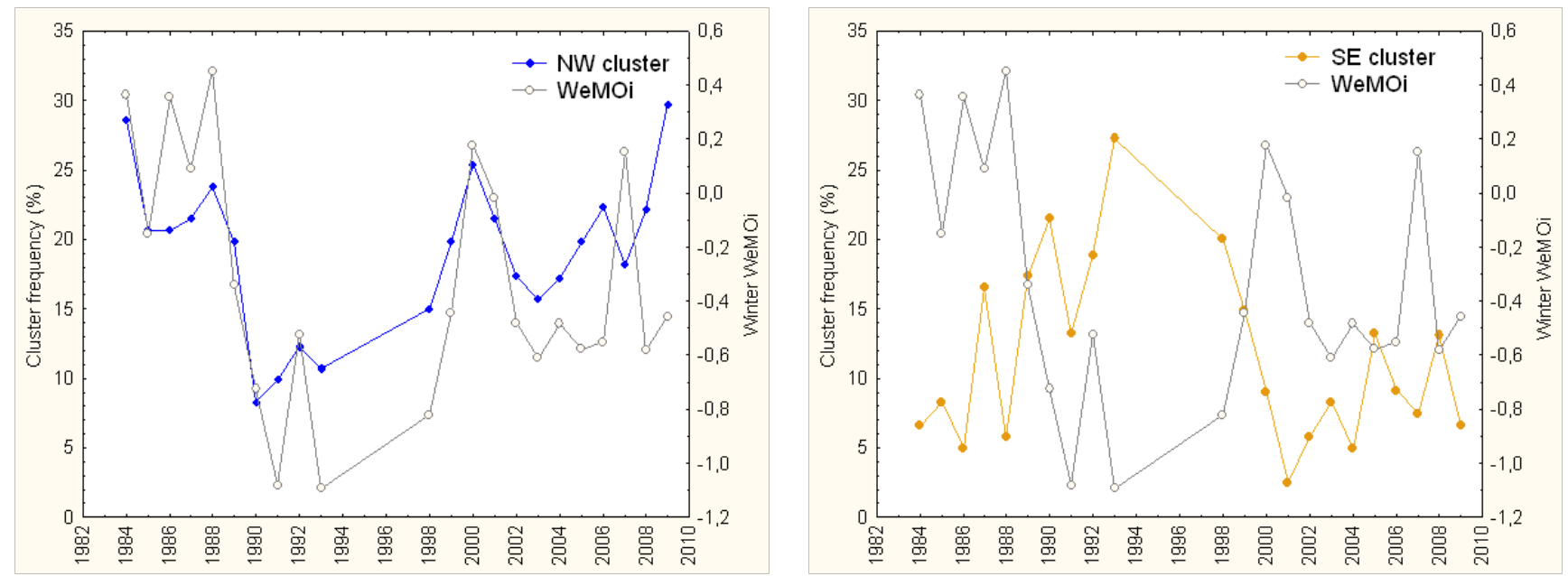

Figure 4. Temporal variation of (a, left) NW and (b, right) SE cluster frequencies and WeMOi in winter (DJFM), with color indicating: positive (blue) or negative (yellow) correlation to WeMOi. Period from 1984 to 2009.

Table 1. Frequency of rainy days for each cluster in winter (DJFM). Data from 1984 to 2009.

\begin{tabular}{lcc}
\hline Clusters & N Rainy days & $\begin{array}{c}\text { Rainy days } \\
\text { vs. } \\
\text { total rainy days (\%) }\end{array}$ \\
\hline C1. N & 74 & 5.1 \\
C2+C8a. NW & 224 & 15.4 \\
C3. W fast & 82 & 5.6 \\
C4. W slow & 180 & 12.3 \\
C5. SW & 250 & 17.1 \\
C6. SE & 202 & 13.8 \\
C7. Regional & 342 & 23.4 \\
C8b. NE & 105 & 7.2 \\
Total & 1459 & $100 \%$ \\
\hline
\end{tabular}

scale circulation features. Indeed, $850 \mathrm{hPa}$ is the most representative level for transport in the lower troposphere. This layer is typically sensitive to cyclonic-wave features and is the approximate boundary between the surface-wind regime and the free troposphere (Artz et al., 1985). Moreover, a relationship between the $850 \mathrm{hPa}$ wind direction and the prevailing weather patterns associated with the passage of cyclonic waves is well established (Dayan and Lamb, 2003).

For the cluster analysis of back-trajectories, the HYSPLIT cluster module was used. It is based on maximizing the Total Spatial Variance (TSV) between clusters and minimizing the spatial variance (SPVAR) within them (Draxler et al., 2009). The final number of clusters is determined by a change in TSV as clusters are iteratively paired. Cluster analysis was applied in two steps. First, it was applied to daily back trajectories, comparing an early (1984-1993) and recent (1998-2009) period in winter. Then, and based on the fact that similar clusters had a similar frequency of occurrence in the two distinct periods (Figure 3), the whole period was analyzed (1984-2009) for winter rainy days (DJFM). In the three exercises (early and recent period, and all data) the same 8 main clusters were consistently obtained: N, NW moderate, NW fast, $\mathrm{W}$ fast, $\mathrm{W}$ slow, SW, SE, and Regional.

VWM concentrations (in $\mu \mathrm{eq} \mathrm{L}^{-1}$ ) and wet deposition amount (in $\mathrm{kg} \mathrm{ha}^{-1}$ year $^{-1}$ ) were calculated for each cluster. The relationship of VWM concentrations and deposition of rain components to the WeMOi was explored with linear least square regressions. Significance of the correlations was set to $p<0.05$.

\section{Results and discussion}

\subsection{The influence of winter WeMO on atmospheric transport routes}

Transport patterns for air masses arriving at LC were identified by cluster analysis and 8 main transport routes were found. Figure 3 shows winter frequencies for each cluster. Significant correlations of cluster frequency with winter WeMOi are highlighted. Fast NW $(r=0.67, p<0.01$; Figure $4 \mathrm{a})$ and $\mathrm{W}(r=0.46, p<0.05)$ clusters were positively correlated while the SE cluster was negatively correlated with winter WeMOi $(r=-0.60, p<0.01$; Figure $4 \mathrm{~b}$ ). Therefore, the positive WeMO phase, which corresponds to the anticyclone over the Azores enclosing the south-west Iberian quadrant and low-pressures in the Ligurian Sea would trigger fast Atlantic fluxes. The negative phase, which arises from a central European anticyclone located north of the Italian peninsula and a low-pressure centre in the south-west Iberian Peninsula, was consistently correlated with the Mediterranean cluster.

The positive WeMO phase is therefore a major influence on winter air mass fluxes to the NE IP, since the sum 


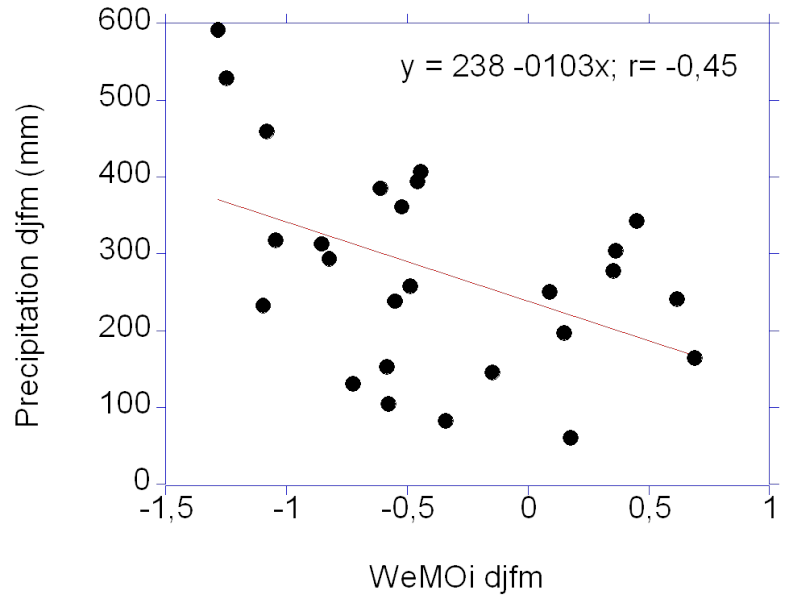

Figure 5. Relationship between the amount of precipitation and WeMOi for winter (DJFM). Period from 1984 to 2009.

of $\mathrm{NW}+\mathrm{W}$ clusters accounted for $24-34 \%$ of daily back trajectories. The negative phase, associated to SE fluxes, accounted for $9-14 \%$ of daily back trajectories (Figure 3). Therefore, both WeMO phases would account for 33-48\% of the winter days air fluxes. However, when considering the frequency of rainy days, $\mathrm{NW}+\mathrm{W}$ provenances had a similar impact in winter $(21 \%)$ as other provenances not connected to WeMO (e.g. the regional cluster, $23 \%$, Table 1), while the SE cluster only accounted for $14 \%$ of the rain days.

\subsection{The influence of winter WeMOi on the amount of precipitation, rain chemistry and deposition fluxes}

The total amount of winter precipitation (regardless of provenance) at LC showed a negative significant correlation with winter WeMOi $(r=-0.45 ; p<0.01$; Figure 5). This is consistent with other studies on the role of WeMO on precipitation on the eastern Mediterranean side of the Iberian Peninsula (Martín-Vide and López-Bustins, 2006; GonzalezHidalgo et al., 2009), and adds to their work in confirming that the precipitation variability in winter in this region can be described with this index.

Washout-related ions are strongly depleted from the atmosphere as rain proceeds, thus showing a negative relationship with rain amount (Prado-Fiedler, 1990). Because the WeMOi is also negatively related to precipitation, a direct relationship between ion concentrations and WeMOi could be envisaged. However, our data showed non-significant relationships between rainfall concentrations for all analyzed ions in the winter period and the WeMOi (Table 2).

Deposition amounts and WeMOi presented significant correlations for some ions $\left(\mathrm{Na}^{+}, \mathrm{K}^{+}, \mathrm{Mg}^{2+}, \mathrm{NO}_{3}^{-}\right.$and $\mathrm{Cl}^{-}$; both the amount of precipitation and deposition of these ions negatively varied with winter WeMOi (Table 2). Because negative WeMO fluxes carry air masses from the Mediterranean, for sea-salt related ions $\left(\mathrm{Na}^{+}, \mathrm{Cl}^{-}, \mathrm{Mg}^{2+}\right)$ this is an
Table 2. Significant correlation coefficients $(\mathrm{R})(p<0.05)$ between winter (DJFM) WeMOi and winter chemical components in precipitation. Data from 1984 to 2009.

\begin{tabular}{lcc}
\hline Ion & Mean conc. & Wet deposition \\
\hline $\mathrm{H}^{+}$ & n.s. & n.s. \\
$\mathrm{Na}^{+}$ & n.s. & -0.45 \\
$\mathrm{~K}^{+}$ & n.s. & -0.39 \\
$\mathrm{Ca}^{2+}$ & n.s. & n.s. \\
$\mathrm{Mg}^{2+}$ & n.s. & -0.43 \\
$\mathrm{NH}_{4}^{-}$ & n.s. & n.s. \\
$\mathrm{NO}_{3}^{-}$ & n.s. & -0.41 \\
$\mathrm{SO}_{4}^{2-}$ & n.s. & n.s. \\
$\mathrm{Cl}^{-}$ & n.s. & -0.39 \\
\hline
\end{tabular}

expected result. However, for $\mathrm{NO}_{3}^{-}$which is emitted mostly from traffic, power generation and industrial activities, this result suggests the presence over the Mediterranean of advection polluted air masses that would carry the emissions from these activities in southern Europe into the Mediterranean coast, and then they would be delivered by Mediterranean rain events. In fact, Millán et al. (1997) have demonstrated that a recirculation process of air masses occurs over the Western Mediterranean that favors the accumulation of atmospheric anthropogenic pollutants across the area. These pollutants are probably incorporated into the rain during negative WeMO phases producing the enhanced deposition observed for $\mathrm{NO}_{3}^{-}$during negative WeMOi. However, local emissions may also play a role. Nitrate aerosol levels at Montseny exhibit a strong seasonal variability, with highest concentrations during the colder winter months, especially during the winter anticyclonic episodes (WAE) and are considerably reduced in the summer (Pey et al., 2009, 2010; Cusack et al., 2012). This pattern is related to the thermal instability of the ammonium nitrate (Harrison and Pio, 1983; Querol et al., 2004). Extremely intense nitrate episodes have been described associated with the transport by mountain breezes of aged air masses from the surrounding industrial/urban areas during WAE in winter (Pérez et al., 2008). At the end of the WAE, stagnant polluted air masses are replaced by air masses coming from Mediterranean or Atlantic (Pey et al., 2010). As Mediterranean episodes are related with the occurrence of precipitation (Pérez et al., 2008), $\mathrm{NO}_{3}^{-}$from regional anthropogenic emissions may be incorporated into rainfall and contribute to the correlation with the WeMOi.

Abatement measures have succeeded in reducing $\mathrm{SO}_{2}$ emissions at a European scale: $\mathrm{SO}_{2}$ emissions fell by $44 \%$ in the EEA-32 countries between 2001 and 2010 (EEA, 2012); and $\mathrm{SO}_{4}^{-2}-\mathrm{S}$ deposition in precipitation has declined accordingly in Europe (Fowler et al., 2007) including in the NE IP (Àvila and Rodà, 2012). The steep declining trend of $\mathrm{S}$ emissions implies that in some sites, $\mathrm{NO}_{3}^{-}$has replaced $\mathrm{SO}_{4}^{-2}$ as the major acid pollutant (Fowler et al., 2007). Also, the reduction of S emissions have modified the formation of nitrate 
aerosols, since atmospheric ammonia is first used to neutralize sulfate to form ammonium sulfate aerosols and particulate nitrate can only be formed when excess ammonia is available. With declining $\mathrm{SO}_{2}$ in the atmosphere, nitrate aerosol concentrations have been found to be $25 \%$ higher than expected if $\mathrm{SO}_{2}$ emissions were not reduced (Fagerli and Aas, 2008), consequently the formation of ammonium nitrate may have contributed to the increase of $\mathrm{NO}_{3}^{-}$rain concentration at LC. This reduction of $\mathrm{S}$ emissions may explain the lack of correlation of sulfate deposition and the WeMO index (Table 2).

\section{Conclusions}

This study has demonstrated a significant correlation of winter WeMOi with the atmospheric circulation patterns during winter in the last 25 years. The cluster classification of provenances at a site in the NE Iberian Peninsula indicated that fast Atlantic air flows corresponded to positive WeMO indices, while negative WeMOi were associated to Mediterranean circulations in winter. Similar to other works, the amount of precipitation was inversely correlated with WeMOi in winter. Non significant relationships between winter WeMOi and rainfall ion concentrations were observed. For deposition, wet deposition fluxes of marine-derived $\left(\mathrm{Na}^{+}\right.$, $\mathrm{Mg}^{2+}$ and $\left.\mathrm{Cl}^{-}\right)$and anthropogenic-derived $\left(\mathrm{NO}_{3}^{-}\right.$and $\left.\mathrm{K}^{+}\right)$ ions were negatively correlated with winter WeMOi. For marine ions, this indicates the incorporation of sea spray into rain as the negative phase of WeMO causes the transport of air masses from the Mediterranean into the Iberian Peninsula. For $\mathrm{NO}_{3}^{-}$, this suggests the advection over the Mediterranean of polluted air masses from southern Europe and their incorporation into the rain. Additionally, local anthropogenic emissions associated with winter anticyclonic episodes may also play a role in the increase of $\mathrm{NO}_{3}^{-}$rain concentration at $\mathrm{LC}$ during the negative WeMO phases.

Acknowledgements. We would like to acknowledge the financial support of the Spanish Government (CGL2012-39523C02-02, CGL2009-13188-C03-01, CGL2009-11205, CSD200800040-Consolider Montes grants and CSD 2007-00067-Consolider GRACCIE). We would also thank Javier Martín-Vide and Joan Albert López-Bustins of the Climatology Group (University of Barcelona) for the WeMOi data, and Mirna Lopez for assistance with the back-trajectory analysis.

\section{References}

Artz, R., Pielke, R. A., and Galloway, J., 1985: Comparison of the ARL/ATAD constant level and the NCAR isentropic trajectory analyses for selected case studies, Atmos Environ, 19, 47-63.

Àvila, A., 1996: Time trends in the precipitation chemistry at a mountain site in Northeastern Spain for the period 1983-1994, Atmos Environ, 36, 2881-2890.

Àvila, A. and Rodà, F., 2012: Changes in atmospheric deposition and streamwater chemistry over 25 years in undisturbed catch- ments in a Mediterranean environment, Sci Total Environ, 434, $18-27$.

Calbó, J., Sanchez-Lorenzo, A., Barrera-Escoda, A., and Cunillera, J., 2012: Climate change projections for Catalonia (NE Iberian Peninsula). Part II: Integrating several methodologies, Tethys, 9, 13-24.

Cusack, M., Alastuey, A., Pérez, N., and Querol, X., 2012: Trends of particulate matter $(P M 2,5)$ and chemical composition at a regional background site in the Western Mediterranean over the last nine years (2002-2010), Atmos Chem Phys, 12, 8341-8357.

Dayan, U. and Lamb, D., 2003: Meteorological indicators of summer precipitation chemistry in central Pennsylvania, Atmos Environ, 37, 1045-1055.

Draxler, R. R. and Rolph, G. D., 2003: HYSPLIT (HYbrid SingleParticle Lagrangian Integrated Trajectory) Model access via NOAA ARL READY website (http://www.arl.noaa.gov/ready/ hysplit4.html), NOAA Air Resources Laboratory, Silver Spring, MD.

Draxler, R. R., Stunder, B., and Rolph, G. D., 2009: HYSPLIT_ 4 User's Guide, NOAA Air Resources Laboratory, http://www.arl. noaa.gov/documents/reports/hysplit_user_guide.pdf.

EEA, 2012: Air quality in Europe - 2012 report, European Environment Agency's Topic Centre for Air and Climate Change Mitigation (ETC/ACM), Copenhagen, Denmark, $10 \mathrm{pp}$.

Escudero, M., Stein, A., Draxler, R. R., Querol, X., Alastuey, A., Castillo, S., and Avila, A., 2006: Determination of the contribution of northern Africa dust source areas to PM10 concentrations over the central Iberian Peninsula using the Hybrid Single. Particle Lagrangian Integrated Trajectory model (HYSPLIT) model, J Geophys Res, 111, D06 210.

Escudero, M., Querol, X., Avila, A., and Cuevas, E., 2007: Origin of the exceedances of the European daily PM limit value in regional background areas of Spain, Atmos Environ, 41, 730-744.

Fagerli, H. and Aas, W., 2008: Trends of nitrogen in air and precipitation: Model results and observation at EMEP sites in Europe, 1980-2003, Environ Pollut, 154, 448-461.

Fowler, D., Smith, R., Muller, J., Cape, J. N., Sutton, M., Erisman, W. E., and Fagerli, H., 2007: Long term trends in sulphur and nitrogen deposition in Europe and the cause of non-linearities, Water, Air and Soil Pollution, 7, 41-47.

Gonzalez-Hidalgo, J. C., Lopez-Bustins, J. A., Stepánek, P., MartinVide, J., and de Luis, M., 2009: Monthly precipitation trends on the Mediterranean fringe of the Iberian Peninsula during the second-half of the twentieth century (1951-2000), Int J Climatol, 29, 1415-1429.

Harrison, R. M. and Pio, C., 1983: Size differentiated composition of inorganic aerosol of both marine and continental polluted origin, Atmos Environ, 17, 1733-1738.

IPCC, 2007: Climate Change 2007. The Physical Science Basis, Solomon, S., Qin, D., Manning, M., Chen, Z., Marquis, M., Averyt, K.B., Tignor, M., Miller, H.L. (Eds.), Contribution of Working Group I to the Fourth Assessment Report of the Intergovernmental Panel on Climate Change. Cambridge University Press, Cambridge, United Kingdom and New York, NY, USA, 996 pp.

Izquierdo, R. and Àvila, A., 2012: Comparison of collection methods to determine atmospheric deposition in a rural Mediterranean site (NE Spain), J Atmos Chem, 69, 351-368.

Izquierdo, R., Àvila, A., and Alarcón, M., 2012: Trajectory statistical analysis of atmospheric transport patterns and trends in precipitation chemistry of a rural site in NE Spain in 1984-2009, Atmos Environ, 61, 400-408. 
López-Bustins, J. A., Martin-Vide, J., and Sánchez-Lorenzo, A., 2008: Iberia winter rainfall trends based upon changes in teleconnection and circulation patterns, Global and Planetary Change, 63, 171-176.

Lovett, G. M., 1994: Atmospheric deposition of nutrients and pollutants in North America: an ecological perspective, Ecol Appl, 4, 629-650.

Martín-Vide, J. and López-Bustins, J. A., 2006: The Western Mediterranean Oscillation and rainfall in the Iberian Peninsula, Int J Climatol, 26, 1455-1475, http://www.ub.edu/gc/English/ wemo.htm.

Millán, M. M., Artíñano, B., Alonso, L. A., Navazo, M., and Castro, M., 1991: The effect of meso-scale flows on regional and longrange atmospheric transport in the Western Mediterranean area, Atmos Environ, 25, 949-963.

Millán, M. M., Salvador, R., Mantilla, E., and Kallos, G., 1997: Photooxidant dynamics in the Mediterranean basin in summer: results from European research projects, J Geophys Res, 102, 8811-8823.

Pérez, N., Pey, J., Castillo, S., Viana, M., Alastuey, A., and Querol, X., 2008: Interpretation of the variability of levels of regional background aerosol in the Western Mediterranean, Sci Total Environ, 407, 527-540.

Pey, J., Pérez, N., Castillo, S., Viana, M., Moreno, T., Pandolfi, M., López-Sebastián, J. M., Alastuey, A., and Querol, X., 2009: Geochemistry of regional background aerosols in the Western Mediterranean, Atmos Res, 94, 422-435.

Pey, J., Pérez, N., Querol, X., Alastuey, A., Cusack, M., and Reche, C., 2010: Intense Winter atmospheric pollution episodes affecting the Western Mediterranean, Sci Total Environ, 408, 19511959.

Prado-Fiedler, R., 1990: On the relationship between precipitation amount and wet deposition of nitrate and ammonium, Atmos Environ, 24, 3061-3065.

Querol, X., Alastuey, A., Rodríguez, S., Viana, M. M., Artíñano, B., Salvador, P., Mantilla, E., García do Santos, S., Fernandez-Patier, R., de la Rosa, J., Sanchez de la Campa, A., Menéndez, M., and Gil, J. J., 2004: Levels of PM in rural, urban and industrial sites in Spain, Sci Total Environ, 334-335, 359-376.

Rodríguez, S., Querol, X., Alastuey, A., and Mantilla, E., 2003: Events affecting levels and seasonal evolution of airborne particulate matter concentrations in the Western Mediterranean, Environ Sci Technol, 37, 216-222.

Salvador, P., Artíñano, B., Querol, X., Alastuey, A., and Costoya, M., 2007: Characterisation of local and external contributions of atmospheric particulate matter at a background coastal site, Atmos Environ, 41, 838-845.

Seinfeld, J. A. and Pandis, S. N., 1998: Atmospheric Chemistry and Physics: From Air Pollution to Climate Change, John Wiley and Sons, Inc., New York. 